\title{
KEPEMIMPINAN TRANSFORMASIONAL KEPALA SEKOLAH DALAM MENGHADAPI PERMASALAHAN DI SEKOLAH MENENGAH ATAS
}

(The Principal's Transformational Leadership In Dealing With Problems At High School)

\author{
Nurkholifatul Maula \\ Universitas Negeri Yogyakarta \\ Kampus Karangmalang Jl. Colombo No. 1 Depok, Sleman Yogyakarta \\ Email : maulanurkholifatul89@gmail.com
}

\begin{abstract}
In the era of industrial revolution 4.0, leadership plays an important role in developing the quality of human resources. This is related to education. One of type of leadership that is appropriate for this era is the type of transformational leadership. The informants of this study were the principal of SMAN 1 Pakem. Data collection by conducting in-depth interviews, approaching in this study using qualitative, which was analyzed by Miles and Huberman analysis techniques. there are several berriers faced by SMAN 1 Pakem. Among them are: decreasing student achievement, morality problems, and the challenge of SMAN 1 Pakem in graduating students in college. Based on the problems faced, the school principal carried out several strategies. Among them are evaluating policies that have been carried out by the previous principal, giving motivation and facilities to students and teachers for their development. Applying the principle of social entrepreneurs in order to foster social sensitivity, and to deepen material with the same age.
\end{abstract}

Key Words: Transformational Leadership, Principals, and Problems.

\begin{abstract}
Abstrak
Era revolusi industri 4.0, kepemimpinan memegang peranan penting guna mengembangkan kualitas sumber daya manusia. Hal ini kaitannya dalam bidang pendidikan. Salah satu tipe kepemimpinan yang tepat untuk era ini ialah tipe kepemimpinan transformasional. Informan penelitian ini yaitu kepala sekolah SMAN 1 Pakem. Pengumpulan data dengan melakukan wawancara mendalam, penedekatan pada penelitian ini dengan menggunakan kualitatif, yang dianalisis menggunakan teknik analisis Miles and Huberman. SMAN 1 Pakem memiliki beberapa tantangan yang dihadapi. Diantaranya yaitu: menurunnya prestasi siswa, masalah moralitas, dan tantangan SMAN 1 Pakem dalam kelulusan siswa nya di perguruan tinggi. Berdasarkan permasalahan yang dihadapi tersebut, kepala sekolah melakukan beberapa strategis. Diantaranya yaitu melakukan evaluasi kebijakan yang telah dilakukan oleh kepala sekolah sebelumnya, pemberian motivasi dan fasilitas kepada siswa dan guru untuk pengembangan mereka. Menerapkan prinsip social entrepreneur guna menumbuhkan kepekaan sosial, dan melakukan pendalaman materi dengan tentor sebaya.
\end{abstract}

Kata Kunci: Kepemimpinan, Transformasional, Kepala Sekolah, dan Permasalahan.

\section{PENDAHULUAN}

Kualitas pendidikan di Indone-

sia memiliki banyak tantangan, diantaranya dikutip dari laman Lembaga Pengembangan Pemberdayaan Kepala Sekolah (LPPKS), yaitu guru dan kepala sekolah memiliki keter-batasan wawasan, sempitnya pola pikir, kurangnya kualifikasi dan ino-vasi. Terlebih lagi ditambah dengan mulai munculnya revolusi industri 4.0 memiliki tantangan yang semakin besar.

Era revolusi industri 4.0 memberikan dampak, salah satunya adalah bidang pendidikan. Ada 
beberapa hal perubahan-perubahan dalam bidang pendidikan selama era revolusi industri 4.0 yaitu, model pendidikan yang berubah dari tradisional menjadi modern.

Revolusi Industri 4.0 salah satunya dicirikan dengan mulai adanya dominasi penggunaan internet. Oleh karena itu, revolusi industri 4.0 harus direspon secara tepat. Faktor sumber daya manusia sebagai pengendali pada era ini perlu diperhatikan kualitasnya. Berbicara mengenai pengembangan sumber daya manusia, tidak terlepas dari peran seorang pemimpin. Pemimpin memiliki peran yang penting dalam sebuah organisasi. Begitupun juga dengan sebuah pendidikan, seorang kepala sekolah menjadi tolok ukur untuk ketercapaian visi dan misi sebuah sekolah.

Upaya dalam menghadapi tantangan atau permasalahan di sekolah membutuhkan usaha besar dari seluruh komponen sekolah, baik dari kepala sekolah dan para guru. Strategi dalam menghadapi tantangan di sekolah harus didukung secara sinergis oleh kepala sekolah, guru, dan siswa didalamnya.
Rivai dan Mulyadi (2009), menyatakan bahwa pemimpin merupakan faktor penentu dalam kesuksesan suatu organisasi. Pemimpin yang sukses memiliki beberapa kriteria. Diantaranya mampu mengelola organisasi, bisa mempengaruhi secara konstruktif orang lain dan menunjukkan jalan serta perilaku yang benar.

Pendapat di atas sejalan dengan temuan yang disampaikan Gary Yukl (1998:304-307) bahwa kepemimpinan transformasional hadir menjawab tantangan zaman yang penuh dengan perubahan. Kepemimpinan transformasional yang efektif, yaitu pemimpin yang melihat dirinya sebagai agen perubahan, pemimpin berhati-hati dalam mengambil risiko, peka terhadap kebutuhan organisasi, mempunyai keterampilan kognitif dan memiliki visi yang mempercayai institusi mereka.

SMAN 1 Pakem mengalami beberapa tantangan pada tahun 2012 sampai tahun 2016. Adapun tantangan yang dihadapi saat itu ialah rendahnya prestasi siswa. Pada tahun 2016, kepala sekolah tersebut mulai melakukan beberapa 
strategi guna menghadapi dengan melakukan wawancara permasalahan yang ada di sekolah.

Berdasarkan beberapa strategi yang telah dilakukan oleh kepala sekolah, sejalan dengan model kepemimpinan transformasional yang disebutkan oleh Bass (1985) dan Leithwood (2010) beberapa dimensi kepemimpinan transformasional dian-taranya ialah : menetapkan arah (visi dan misi), mengembangkan orang/ staf, menata ulang organisasi dan mengelola program instruksional.

Adapun penelitian ini bertujuan untuk mengidentifikasi permasalahan yang dihadapi SMAN 1 Pakem dan mendeskripsikan strategi kepemimpinan kepala sekolah dalam menghadapi permasalahan-permasalahan tersebut.

\section{METODE PENELITIAN}

Penelitian ini menggunakan pendekatan kualitatif. Sejalan dengan pendapat dari Gunawan (2014:85) menyatakan bahwa penelitian kua-litatif bertujuan untuk mendapatkan pemahaman yang mendalam tentang masalah-masalah sosial. Pengum-pulan data dilakukan

mendalam.

Adapun analisis pada penelitian ini yaitu dengan menggunakan teknik analisis Miles and Huberman. Houghton, Shaw dan Casey (2015) teknik analisis Miles and Huberman ada beberapa tahapan, yaitu : memahami, mensintesa, teoritisasi, dan rekontekstualisasi.

Informan penelitian ini yaitu kepala sekolah, wakil kepala akademik, guru dan siswa. Penelitian ini bertempat pada SMAN 1 Pakem yang berlokasi di Jalan Kaliurang KM 17,5 Pekambinangun, Pakem, Gambiran, Sleman-DI Yogyakarta.

\section{PEMBAHASAN}

Kepala Sekolah Sman 1 Pakem Menghadapi Permasalahan Karakter Dan Prestasi Siswa

SMAN 1 Pakem mengalami beberapa permasalahan sejak tahun 2012 sampai pada tahun 2016. Diantaranya yaitu : kenakalan yang cukup tinggi dan prestasi yang menurun. Hal ini didukung dengan adanya pernyataan dari Bapak Kristya Mintarja sebagai kepala sekolah, yang menyatakan bahwa : "Dulu sering terjadi tawuran dan nilai 
UN yang kecil". Akan tetapi pada tahun-tahun tersebut fokus pengembangan pada perbaikan sarana dan prasarana sekolah.

Merujuk pada hasil wawancara wakil kepala sekolah bidang akademik, ada beberapa faktor yang menyebabkan penurunan prestasi siswa SMAN 1 Pakem. Diantaranya ialah : pelaksanaan kurikulum yang kurang maksimal, perencanaan materi dan startegi pembelajaran yang kurang matang sehingga kurang tepat sasaran.

Seiring perkembangan strategi yang telah dilakukan oleh kepala sekolah di awal tahun 2016, tantangan yang dihadapi kepala sekolah perihal studi lanjut siswa SMAN 1 Pakem. Maksud dari studi lanjut ini secara gamblang yaitu capaian-capaian sekolah dengan besaran nilai Ujian Nasional dan kelulusan siswa untuk masuk perguruan tinggi. Hal ini lebih terfokus pada cara untuk mempersiapkan siswa ke perguruan tinggi.

Disisi lain, sejalan dengan prestasi dan tingkat kelulusan siswa untuk masuk perguruan tinggi, pendidikan karakter menjadi sebuah salah satu strategi untuk mengurangi kenakalan pada siswa di SMAN 1 Pakem.

Pergantian kepala sekolah dan budaya yang telah ada pada kepala sekolah sebelumnya menjadi sebuah tantangan tersendiri untuk menyusun strategi-startegi baru. Hal itu dialami oleh Bapak Kristya Mintarja sebagai kepala sekolah SMAN 1 Pakem yang mulai menjabat pada tahun 2016, sedangkan kepala sekolah sebelumnya berfokus pada pengembangan sarana dan prasarana, sehingga pengembangan prestasi siswa sedikit terbengkalai.

\section{Strategi Kepemimpinan Transfor- masional Kepala Sekolah SMAN 1 Pakem}

Berdasarkan beberapa permasalahan yang dihadapi oleh SMAN 1 Pakem yang telah disebutkan di atas, kepala sekolah SMAN 1 Pakem telah menerapkan beberapa strategi untuk menangani permasalahan tersebut. Adapun strategi dibagi sesuai dengan dimensi kepemim-pinan transformasional. Leithwood (2010), yaitu menetapkan arah (visi dan misi), mengembangkan orang/ staf, 
menata ulang organisasi dan mengelola program instruksional.

\section{a. Strategi Kepala Sekolah Dalam Menetapkan Arah (Visi dan Misi)}

Sebagai kepala sekolah yang baru saja menjabat pada tahun 2016 yang tentunya bertugas untuk melakukan estafet kepemimpinan kepala sekolah sebelumnya menjadi tantangan tersendiri bagi Pak Kristya Mintaraja. Terlebih dalam melakukan strategi untuk merumuskan visi dan misi di sekolah. Sebagai kepala sekolah di era revolusi industri 4.0, perlu adanya kemampuan kepekaan dalam membaca situasi saat ini, masa depan dan membandingkannya dengan kebijakan yang telah ada pada kepala sekolah sebelumnya. Setelah semuanya telah dipelajari dengan runtut, barulah dapat merumuskan untuk membentuk strategi yang akan dilakukan untuk menyelesaikan permasalahan yang dihadapi sekolah.

Hal tersebut sejalan dengan pernyataan yang telah diungkapkan oleh pak Kristya Mintara sebagai kepala sekolah SMAN 1 Pakem :
"Sebelum kita menentukan strategi yang akan dilakukan, tentunya kita perlu mengevaluasi kebijakan yang telah diterapkan oleh kepala sekolah sebelumnya".

Dalam kaitannya strategi yang dilakukan oleh kepala sekolah untuk menangani penurunan prestasi di kelas. Kepala sekolah memilih jalan untuk melakukan diskusi dengan para guru dan siswa. Memotivasi juga menjadi salah satu strategi yang dilakukan oleh kepala sekolah, motivasi diberikan secara berkala kepada siswa dan sering juga kepada karyawan atau para guru. Hal ini dilakukan guna menciptakan kegairahan dalam iklim belajar. Dengan adanya pemberian motivasi secara berkala ini, diharapkan akan memunculkan harapan kinerja yang baik kepada guru atuapun siswa.

Pemberian motivasi dilakukan dengan cara mengundang beberapa tokoh secara bergantian yang dilakukan selama satu bulan satu kali. Kegiatan ini diharapkan tokohtokoh tersebut dapat menceritakan pengalaman mereka kepada siswa SMAN 1 Pakem sehingga dapat memunculkan keinginan siswa untuk berprestasi seperti tokoh tersebut. 
Kegiatan ini tidak dinamai secara kontekstual sebagai pemberian motivasi. Melainkan dinamai dengan "sarasehan budaya". Terdapat alasan tersendiri dari penamaan ini agar tidak terkesan terlalu formal. Kegiatan ini juga sebagai salah satu sarana cara kepala sekolah dalam mengartikulasikan visi sekolah kepada guru dan siswa. Sehingga secara tanpa disadari, guru dan siswa dapat memahami dan mengikuti visi yang telah ditetapkan sekolah tanpa merasa dipaksa.

Sarasehan budaya merupakan suatu kegiatan pemberian motivasi untuk para siswa dan guru. Kegiatan ini selalu mendatangkan orang-orang ahli dibidangnya untuk berdiskusi dan memberikan motivasi kepada seluruh warga sekolah SMAN 1 Pakem. Lebih dalam lagi, sarasehan budaya bertujuan untuk membangun impian siswa dan meningkatkan kinerja guru.

\section{b. Strategi Kepala Sekolah dalam Mengembangkan Orang/Staf di Sman 1 Pakem}

Salah satu strategi kepala sekolah yang memiliki gaya kepemimpinan transformasional dengan melakukan strategi melalui pengembangan orang/staf di SMAN 1 Pakem. Guna meningkatkan capaian akademik, kepala sekolah melakukan strategi dengan memberikan motivasi secara berkala dan memfasilitasi siswa dalam meningkatkan pres-tasinya. Dalam hal ini kepala sekolah juga memanfaatkan sarana dan prasarana yang telah tersedia sebelumnya.

Ada beberapa fasilitas yang diberikan sekolah dalam tujuannya untuk meningkatkan prestasi siswa. Diantaranya yaitu pendalaman materi dan ekstrakurikuler. Pendalaman materi ini dilakukan dengan melakukan kolaborasi antara guru dari internal sekolah dengan guru dari eksternal sekolah.

Adapun maksud dari kolaborasi dengan guru internal sekolah, yaitu melakukan bimbingan dengan mengambil sumber daya guru dari SMAN 1 Pakem dan yang dimaksud dengan berkolaborasi dari guru eksternal sekolah, yaitu dengan mengundang guru dari luar untuk melakukan bimbingna di sekolah. Hal ini bertujuan untuk memperkaya 
wawasan siswa dan menumbuhkan percaya diri siswa dalam proses pembelajaran. Proses pendalaman materi diserahkan kepada siswa. Siswa diberikan kebebasan untuk memilih pendamping dalam pendalaman materinya.

Selain bergantung dari sumber daya guru, kepala sekolah SMAN 1 Pakem juga memiliki inovasi baru dengan mengadakan gerakan tutor sebaya. Gerakan tutor sebaya yang dimaksud ialah memanfaatkan siswa yang memiliki kemampuan lebih secara kognitif untuk membantu siswa yang lain dalam melakukan pendalaman materi. Tutor sebaya ini dilakukan di luar jam sekolah, dan ketua kelas bertanggung jawab atas pelaksanaan tutor sebaya.

Selain bertujuan untuk meningkatkan pemahaman dalam melakukan pendalaman materi, gerakan tutor sebaya ini juga untuk menghilangkan kesenjangan diantara siswa yang berasal dari keluarga yang kurang mampu dengan siswa yang berasal dari keluarga mampu. Siswa yang tidak mampu juga dapat merasakan materi yang telah disampaikan oleh guru bimbel dari luar.
Pemberian

motivasi

merupakan startegi yang paling diutamakan di SMAN 1 Pakem. Karena kepala sekolah mempercayai bahwa kelemahan yang sebenarnya sedang dihadapi oleh anak-anak di Indonesia adalah membangun impian atau cita-cita. Jika anak-anak tidak memiliki impian sejak remaja, maka akan sulit untuk menggapai impian kedepannya. Dikarenakan kurangnya visualisasi impian. Visualisasi impian salah satunya dilakukan dengan cara mengundang para motivator dari berbagai kalangan. Hal ini bertujuan agar siswa dapat memvisualisasikan impiannya.

Sudah saatnya sekolah bukan lagi sebagai pemberi makan siswa. Sekolah perlu membangun mimpi siswanya kemudian membantunya untuk memvisualisasikan impian mereka sehingga mereka merasa percaya diri dalam menggapai impian mereka. Membangun sebuah impian kepada siswa merupakan suatu modal besar. Hal menarik yang diungkapkan oleh kepala sekolah ketika mengungkapkan strateginya, yaitu : "seharusnya kepala sekolah peka terhadap 
keadaan sekolah saat ini dan memiliki wawasan kedepan terhadap tantangan apa saja yang nanti akan dihadapi oleh siswa nya". Pembelajaran di kelas hanyalah sebagai sebuah sarana saja. Tetapi pada dasarnya perlu adanya pemicu kepada siswa untuk meningkatkan prestasinya. Sedangkan pemicu tersebut berasal dari diri siswa itu sendiri. Pemicu disini berarti motivasi yang dapat meningkatkan prestasi siswa.

Selain fasilitas pemberian motivasi kepada siswa dan guru, juga adanya slogan dari SMAN 1 Pakem yang selalu digaungkan disetiap upacara. Adapun slogan tersebut ialah "Fasilitas Terbatas, Prestasi Tanpa Batas." Slogan tersebut memiliki pesan tersirat yang ditujukan kepada siswa, yaitu agar siswa harus tetap bersemangat dalam menggapai impian tanpa terhalang keadaan dan lingkungan sekitar. Selain meng-gaungkan slogan, disetiap upacara juga dilakukan penyerahan tropi kepada siswa berprestasi. Strategi-strategi tersebut ternyata berhasil meningkatkan capaian tingkatan akademik siswa sekitar $90 \%$.
Terdapat strategi unik yang dilakukan kepala sekolah di SMAN 1 Pakem untuk mengembangkan siswa dan guru, yaitu dengan melakukan banyak motivasi kepada siswa agar siswa dapat terus terpacu untuk berprestasi. Jika siswa sudah memiliki impian dan semangat berprestasi maka secara tidak langsung guru pun akan ikut termotivasi. Hal tersebut dilakukan oleh kepala sekolah karena memiliki pandangan bahwa lebih cepat merubah siswa jika dibandingkan dengan merubah orangtua. Dan itu cukup susah dilakukan. Karena siswa masih ada ruang-ruang yang bisa diberdayakan. Sehingga tidak perlu mendorong-dorong guru untuk melakukan perubahan. Secara logis, jika siswa sudah berubah secara cepat, otomatis guru-guru akan mengikuti jalan para siswa. Pada strategi ini, kepala sekolah meyakini bahwa kondisi psikologis anak-anak akan lebih mudah dibentuk daripada melakukan perubahan yang berpusat pada guru. Karena kondisi psikologis guru lebih kompleks daripada anakanak.

Dilain hal, kepala sekolah juga memberikan contoh atau model yang 
baik kepada seluruh masyarakat SMAN 1 Pakem, yaitu dengan kegemarannya bercengkerama melakukan komunikasi dengan berbagai orang tanpa mempedulikan status orang tersebut. Hal ini menjadi suatu bagian implementasi kepala sekolah sebagai model yang patut dicontoh.

\section{c. Strategi Kepala Sekolah dalam Menata Ulang Organisasi}

Beberapa kegiatan strategi yang telah dilakukan sebelumnya termasuk penataan ulang organisasi.

Dikarenakan strategi yang dilakukan oleh kepala sekolah SMAN 1 Pakem sebagai hasil dari pembelajaran dan evaluasi terhadap kebijakan sebelumnya.

Selain upaya dalam peningkatan prestasi siswa, SMAN 1 Pakem berfokus pula terhadap program pengembangan karakter, yaitu dengan membuat program kantin keikhlasan. Kantin keikhlasan ini memiliki sebuah sistem, siswa bisa membayar dan diperbolehkan juga untuk tidak membayar. Kantin keikhlasan bertujuan untuk membantu siswa yang tidak mampu. Berdasarkan pengamatan dari kepala sekolah, siswa yang berasal dari orang tidak mampu ternyata tidak cukup untuk dibebaskan SPPnya saja. Tetapi mereka masih membutuhkan asupan makanan selama jam sekolah berlangsung. Oleh karena itu setiap hari Rabu dan Jumat diadakannya kantin keikhlasan.

Program ini juga sebagai upaya menumbuhkan budaya kolaborasi dan kepekaan sosial kepada siswa. Kolaborasi dalam hal ini kaitannya yaitu kolaborasi antara siswa dan guru untuk saling bekerjasama dalam membantu siswa yang kurang mampu.

Setelah dilakukan evaluasi, ternyata program kantin keikhlasan berdampak sangat baik bagi siswa dan guru di SMAN 1 Pakem. Dampak tersebut terlihat dalam melakukan kegiatan lainnya. Seperti mudahnya saling berbagi ilmu antar siswa dan ampaknya pun sampai kepada implementasi akademik.

Selain kantin keikhlasan, ada beberapa strategi yang dilakukan oleh kepala sekolah dalam kaitannya untuk menumbuhkan kolaborasi diantara lingkungan sekolah dengan lingkungan masyakarakat, yaitu dengan melaksanakan kurban yang 
dilakukan oleh setiap kelas di SMAN 1 Pakem yang nanti akan disembelih di lingkungan masyarakat. Kegiatan tersebut dapat menciptakan keterlibatan sekolah dalam menyelesaikan permasalahan di masyarakat, selain itu juga mampu menumbuhkan kepercayaan masyarakat terhadap SMAN 1 Pakem.

Selain kegiatan kurban, SMAN 1 Pakem juga membiasakan siswanya untuk membantu sesama temannya yang kesusahan dengan melakukan usaha sendiri. Terdapat beberapa kegiatan yang telah dilakukan. Seperti yang diungkapkan oleh kepala sekolah : "sewaktu akan diadakannya study tour dan ada beberapa teman mereka yang tidak mampu untuk membayar biaya study tournya, sehingga teman-temannya yang lain menjual botol bekas untuk membantu temannya yang tidak mampu agar bisa berangkat".

Dalam upaya melakukan restrukturisasi organisasi membutuhkan pemahaman visi yang sama. Lalu lain halnya jika ada guru baru yang masuk ke SMAN 1 Pakem. Hal tersebut juga dapat menjadi suatu tantangan bagi kepala sekolah. Ada beberapa hal yang dilakukan oleh SMAN 1 Pakem saat ada guru baru, yaitu dengan menyampaikan peraturan yang ada di SMAN 1 Pakem dan memotivasinya juga. Adapun pendekatan yang dilakukan untuk melakukan motivasi kepada para guru, yaitu dengan melakukan pendekatan non-formal. Hal ini bertujuan agar guru yang bersangkutan dapat menerima motivasi dari kepala sekolah secara utuh dan guru dapat menceritakan kendala dalam mengajar tanpa merasa canggung.

Sebelum melakukan sebuah restrukturisasi, kepala sekolah SMAN 1 Pakem biasanya melakukan pendekatan dengan mengajak para guru, siswa dan warga SMAN 1 Pakem lainnya mengobrol dan bercerita tentang kendala-kendala yang dialaminya. Sehingga dari kegiatan tersebut kepala sekolah dapat mengidentifikasikan permasalahan di SMAN 1 Pakem dan dapat membuat perencanaan strategi yang tepat sasaran.

\section{d. Strategi Kepala Sekolah dalam Mengelola \\ Program Instruksional}

Permasalahan yang dihadapi dalam kegiatan belajar mengajar, 
diantaranya yaitu : perencanaan kurikulum, mata pelajaran dan model pembelajaran yang kurang matang. Sehingga kegiatan pembelajaran di sekolah mengalami masalah.

Untuk mengatasi permasalahan tersebut, kepala sekolah, wakil kepala sekolah bidang akademik dan para guru serta perwakilan siswa diajak untuk melakukan rapat bersama. Hal ini bertujuan untuk mengetahui benang merah dari permasalahan yang ada.

Dalam pembuatan perencanaan kurikulum dan model pembelajaran disesuaikan dengan keinginan siswa. Evaluasi pembelajaran seringkali dilakukan oleh kepala sekolah dengan melakukan keliling di setiap kelas pada pagi hari dan menanyakan mengenai kegiatan pembelajaran di kelas.

\section{KESIMPULAN}

1. Terdapat beberapa permasalahan yang dihadapi oleh SMAN 1 Pakem. Diantaranya, yaitu kenakalan yang cukup tinggi dan prestasi yang menurun serta capaiancapaian sekolah dengan besaran nilai Ujian Nasional dan kelulusan siswa untuk masuk perguruan tinggi.

2. Strategi kepala sekolah dalam merumuskan visi dan misinya, yaitu dengan melakukan evaluasi terhadap kebijakan sebelumnya dan melakukan diskusi dengan seluruh sumber daya manusia yang ada di sekolah.

3. Strategi untuk melakukan pengembangan guru dan siswa, yaitu dengan memberikan motivasi secara berkala dan menyediakan fasilitas penunjang untuk pengembangan diri.

4. Strategi dalam melakukan penataan ulang organisasi, yaitu dengan menumbuhkan kepekaan sosial dengan cara berkolaborasi dengan internal sekolah dan lingkungan di luar sekolah.

5. Strategi untuk pengembangan instruksional, yaitu dengan melakukan need assesment para siswa dan guru. Serta melakukan evaluasi dari ketidaktercapaian-nya proses pembelajaran di kelas. 
6. Strategi-strategi yang dilakukan oleh kepala sekolah SMAN 1 Pakem sangat bermanfaat jika penelitian ini dapat dijadikan sebagai sumber referensi bagi kepala sekolah lainnya.

\section{SARAN}

Adapun saran dari penelitian ini, yaitu:

1. Bagi siswa dan guru di sekolah SMAN 1 Pakem agar lebih berkolaborasi dengan baik lagi untuk mewujudkan visi dan misi sekolah.

2. Bagi pemerintah, perlu adanya dukungan dan pelatihan kepada para kepala sekolah.
3. Bagi masyarakat, untuk bisa mendukung dan berkolaborasi dengan program-program di sekolah.

\section{DAFTAR PUSTAKA}

Leithwood. 2010. Transformational School Leadership. Canada: University of Toronto journal.

Vithzal, Rivai dan Deddy Mulyadi. 2009. Kepemimpinan dan Perilaku Organisasi. Jakarta: Raja Grafindo Persada.

Wayne K. Hoy dan Cecil G. Miskel. 2014. Administrasi Pendidikan: Teori, Riset dan Praktik. Yogyakarta: Pustaka Pelajar.

Gary, Yukl. 1998. Kepemimpinan Manajemen. Jakarta Prengallindo. http://lppks. kemdikbud.go.id 